\title{
NIH cuts bring in hard times for biomedical researchers
}

\section{Berkeley}

BIOMEDIC AI training in the United States is in for hard times following a decision by the National Institutes of Health (NIH) to reduce the number of predoctoral and postdoctoral positions it supports. In some institutes it may become impossible to finance new training grants or renew those due to expire.

Training grants provide stipends and tuition expenses for predoctoral graduate students and stipends for postdoctoral trainees, as well as "supply funds" that many departments use to finance seminar series and courses. The squeeze will also reduce the number of individual postdoctoral fellowships.

Close to 1,000 posts were put at risk after Congress refused to appropriate money to pay for an increase in fellowship stipends decided upon by NIH. But some say the crisis has been brewing for years. as funding for NIH training programmes has failed to keep up with the rise in the cost of living and tuition expenses.

The stipend increase "exacerbated a very bad situation", says William Pitlick. research training officer at NIH. But NIH could not ignore criticism by university administrators that the stipend level had not been raised for four years.

According to Pitlick, postdoctoral training grants were intended to encourage people trained as doctors to obtain research experience at the postdoctoral level. But the grants were thousands of dollars less than salaries paid to medical residents and created little incentive for good doctors to enter research. Graduate stipends of $\$ 6,500$ were also unreasonably low, and had to be supplemented substantially by universities. As a result of the increase, graduate stipends will rise from $\$ 6,500$ to $\$ 8,500$, and a third-year postdoctoral fellow who previously would have earned $\$ 21,000$ will now earn $\$ 25,000$ per year.

The National Institute of General Medical Sciences (NIGMS), which finances two-thirds of NIH-sponsored predoctoral training grants, must cut 400 training positions, 300 of them from predoctoral programmes. The Medical Scientist Training Program (MSTP) which funds $\mathrm{MD} / \mathrm{PhD}$ students will lose 155 of its present 725 positions. Institute director Ruth Kirschstein says it is uncertain whether there will be money to fund any new training grants or renew those at the end of their five-year grant period.

Murray Goldstein, director of the National Institute for Neurological Disorders and Stroke (NINDS), sent a ripple of panic through the neuroscience community last month when he informed training grant holders there would be no funds to renew five-year grants. The institute would normally fund 15 to 18 grants. Goldstein says, but this year, "twenty-one training grants are approved for our January meeting, to compete for no dollars".

Among those ill-fated renewal applications are training grants from the neuroscience graduate programmes at the Harvard, Stanford, Columbia and Yale medical schools. Story Landis, of the neuroscience programme at Case Western Reserve University, which also stands to lose its training grant. has started a grassroots movement among neuroscientists to lobby Congress for an increase in funds. The loss of grants will "eviscerate the training environment", says Landis. Not only will it force departments to take fewer students and post-docs, she says, but it will eliminate funds used to support seminar series and graduate student recruitment.

Goldstein agrees that training grants serve an important role, but NINDS training grants support mostly postdoctoral trainees, and Goldstein says that the

money is better spent on individual fellowships, where it can buy more positions. "Given the very difficult situation, do we give that institution money to enrich their programme, at the cost of a fellowship?" At NINDS, for the time being, the answer is no. Training grants that are not funded this year may be re-submitted next year, when there will be some funds available. But the competition will be stiff.

The crisis is not temporary according to Pitlick. Although Congress has always funded stipend increases in the past, the current preoccupation with the national budget deficit has made that unlikely. "At the time we implemented the stipend increase, we discussed the distinct possibility that funds wouldn't be available for it". Pitlick says. "We knew it would cost us trainees if we didn't get more money, and that "s what's happening." With funds as short as they are. many of those affected would prefer that NIH forgo the stipend increase rather than cut positions. Says NIGMS"s Kirschstein, "In this day and age of concern about whether the United States is competitive with other countries in biomedical and particularly biotechnological research, we need to train more people, and we are training fewer."

Marcia Barinaga

\section{More disruption for UK research councils}

\section{London}

THE research councils for the natural environment (NERC) and for agriculture and food (AFRC) will go into a new year battered and bruised after several years of reductions in public resources. There is little sign that the squeeze is coming to an end and more disruption is on the horizon. with a possible merger between the two councils to form a Natural Resources Research Council (NRRC)

The House of Lords select committee on science and technology has recommended such a merger in an interim report on the future of agricultural and food research; the recommendation is welcomed by both councils, though more so by the NERC which recommended the merger. The AFRC, instead, strongly advocated a single council for non-medical biology, which would be called the Biological Resources Council (BRC). bringing together the biological activities of the NERC, the AFRC and the Science and Engineering Research Council (SERC). But the SERC itself is opposed to this, arguing that at present it can encourage collaboration between life scientists and physical and chemical scientists and mathematicians. And many believe it would be a step backwards if studentships in biological sciences were to be handled separately from those in physics, chemistry and engineering.

The Lords committee decided against the formation of a BRC, which, it said. could only have advantages if the council were also responsible for the biological research carried out by the Medical Research Council (MRC); but because of the special character and needs of medical research, the committee decided that the MRC should continue its separate existence. Meanwhile, the formation of a NRRC would remove some of the inappropriate divisions of responsibility between the two councils. The resulting organization will be stronger and more effective than its constituent parts, says the committee. It would be comparable in size to the SERC and the MRC, and so could lead to a better balance within the research council structure. If the government accepts the Lords" advice, following the committee's full report next spring, the councils will then begin to discuss exactly how it should be carried out. The NERC urges that it should be a gradual development; the council's new chairman. Professor John Knill, is cautious about the move and keen that the NERC does not lose its distinct role as the council responsible for the environment, that role being one the government now supports and one with which the public can identify.

If the merger is to go ahead, then both councils will insist that funds for restructuring do not come out of research funds. In their annual reports, both refer with dismay to the reduction in public funding which has led to less research and to redundancies. 